$\frac{\text { DE }}{\mathrm{G}} \stackrel{\substack{\text { DE GRUYTER } \\ \text { OPEN }}}{\text { EOI 10.1515/ethemes-2015-0028 }}$

\title{
AN ANALYSIS OF FACTORS AND EFFECTS OF PRODUCT DESIGN QUALITY
}

\author{
Gorica Bošković \\ University of Niš, Faculty of Economics, Serbia \\ \orica.boskovic@eknfak.ni.ac.rs, \\ Marija Radosavljević \\ University of Niš, Faculty of Economics, Serbia \\ $\triangle$ marija.andjelkovic@eknfak.ni.ac.rs
}

UDC

005.6

Original

scientific paper

\begin{abstract}
The aim of this paper is to highlight the fact that there is a significant relationship between design quality and process quality, and then the quality of the finished products (internal quality) and the later use of the products by the consumers (external quality). The paper outlines the model of the synergy between design management and process management. Since design quality is the first link in this chain of creating quality, it is necessary to adequately carry out the design process, or provide high-quality design. High-quality design includes connectivity and collaboration between functions that can contribute to the design process, such as: research and development, production, marketing and supply. In order to achieve this, it is important to continuously work on education and training of employees. In addition, it is necessary to apply the tools characteristic for providing quality design, but also the common tools important for quality management. Accordingly, the subject of the paper is examining the impact of employee training, the implementation of quality management tools and application tools for quality design as a factor in establishing links between business functions that should be included in the design process. Based on the application of tools such as regression analysis, cluster analysis and correlation analysis, the results of empirical research suggest that these factors affect the establishment of links between the observed business functions, and facilitate providing the quality of the design process.
\end{abstract}

Received:

29.01.2015

Accepted:

19.11.2015

Keywords: design quality, processes quality, business functions, cluster analysis, regression and correlation analysis. 


\section{Introduction}

Quality is one of the goals of production and one of the areas of responsibility for decision making in the company. In order to attain the desired level of quality, it is important to manage all aspects of quality and all dimensions of quality, particularly the quality of design and quality processes.

From the standpoint of quality, special importance has the quality of design, which means that companies have to provide a consistent and costeffective achievement of the desired quality during the process of designing products and related business processes (Bass, 2004). Harmonized quality requires manufacturing process management, in accordance with the created design in order to get products that are in line with the expected specifications (Robinson and Schroeder, 1990; Benton, 1991). In this respect, Deming (1986) argued for effective process management or systematic identification and elimination of defects and their causes during the process because the high quality of the process contributes to creating high-quality products. This means that the quality of the product, its functionality and suitability for use, are directly conditioned by the way designing process has been performed.

To highlight the impact of design quality on the quality of the process and, consequently, on the quality of products, the paper focuses on a certain hypothesis, namely: (1) design management affects the internal quality; (2) design management affects the external quality; (3) process management affects the internal and external quality; (4) design and process management depend on the variables of organizational character and, above all, the experience of the employees related to quality management. The analysis of the experiences and opinion of other authors, used to confirm previously formulated hypotheses, are followed by empirical testing of awareness of managers in Serbia about the importance quality design, as well as analysis of the impact of design quality factors and their effects on the functioning of the company.

\section{The Basic Dimensions of Quality: From Design Quality to Quality of Product Functioning}

When speaking about quality, authors often start from Juran's quality concept, according to which consumers are drivers of quality. Actually, quality management begins and ends with them (Juran, 1992). Juran's definition of quality is the "fitness for use". This definition is very close to Crosby's definition of "appropriate to the requirements" and is considered to be significantly more complete compared to Deming "adequate to the specification", because the performances of the product may be within the defined specifications (standards), but if the specifications are not compliant with the requirements of consumers, providing performances within their boundaries does not lead to satisfaction of those consumers (Gruner, Homburg, 2000). 
According to Juran (1992), the quality can be seen through three dimensions, namely: quality of design, quality of process and the quality of products (services). Bearing in mind that for consumers very significant is stability or sustainability of product quality and after the begining of its usage, Juran's concept of quality should be supplemented by a fourth dimension quality of product functioning. Considering all of the above mentioned, but also observing the quality from the perspective of the manufacturer, it may be noted that there are four stages in quality assurance or four aspects of quality, specifically: quality of design, quality of process, quality of product and quality of performance - functioning, where quality of design and quality of process predetermine the other two aspects of quality.

Quality of design represents compliance of product specifications and appropriate processes with the demands and needs of consumers. It may be called quality of projected solution or quality of construction. Design quality affects the value of the product on the market and is an important aspect of strategic management. While the quality of processes and product means that the characteristics of manufactured goods and services correspond to the specifications or design, design quality concerns coherence of designed characteristics of products and services to the wishes and demands of consumers. Therefore, the basic condition for ensuring quality of design is communication and cooperation with consumers of products that are designed. If the functions and characteristics of the products are determined in cooperation with customers or based on the information about the requirements and desires of the consumers, the design will be effective.

Quality of process involves the efficient use of resources needed for translating the design into a concrete result (product). Most often is determined by checking how the results of certain activities inside the process corespond with defined specifications. It can be described as quality of production. The quality of the process depends on the quality of design, but also the way in which the activities, as part of the process, are realized. The process can be considered quality one if the implementation of the activities is carried out according to the established order, for the estimated time and if there are no defects, as a result of their implementation (because that would mean repeating activities and further waste of resources and time).

Quality of conformance refers to providing characteristics of a product as a result of the process within the defined specifications. It can be presented as a quality of conformance. Quality of conformance (Chase, Jacobs, Aquilano, 2006) is conditioned by the degree of matching the product with its design (specifications). While activities related to the quality of design belong to the field of strategic management, activities which ensure the conformity of products are related to the operations management. It may be marked of product quality. Product quality is a direct consequence of the quality of the process (Lucas, Menon, 2004). 
Kvalitet funkcionisanja (Quality of Performance) - predstavlja podobnost proizvoda za obavljanje određene funkcije u bilo kom trenutku i često se poistovećuje sa pouzdanošću. Kvalitet funkcionisanja proizvoda uslovljen je njegovom usaglašenošću sa specifikacijama, ali i kvalitetom projektovanog rešenja, odnosno kvalitetom dizajna (Van Kleef, Van Trijp, Luning, 2005). To znači da je kvalitet proizvoda, u smislu njegove funkcionalnosti i podobnosti za upotrebu, direktno uslovljen načinom na koji je vođen proces dizajniranja proizoda.

Quality of performance or functioning represents the suitability of the product to perform certain functions at any time and is often identified with reliability. Quality of product's functioning is conditioned by its compliance with specifications, but also the quality of the designed solutions or quality of design (Van Kleef, Van Trijp, Luning, 2005). This means that the quality of product, in terms of its functionality and suitability for use, is directly caused by the way that the design process has been performed.

Fig 1. The quality of design and quality of products as a function of the quality of performance

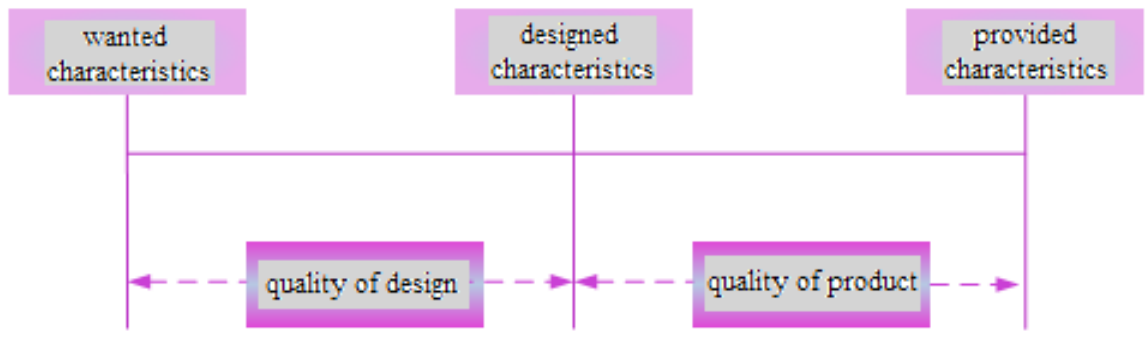

The quality of the performance or reliability is provided by or through the quality of design (Amitav, 1994). In addition, the quality of design is the potential quality, while the quality of product is achieved quality (Figure 1).

\section{The Impact of Design and Process Management on Operating Results of Quality}

To examine the impact of the design and process management to operational quality results, it is necessary to consider several issues that, in essence, represent the research questions in this paper, namely: (1) Does the design management affect the internal quality? (2) Does the design management affect the perception of the quality of products by consumers after its use (external quality)? (3) Does the process management affect the internal and external quality? (4) Is the relative influence of design and process management to the operational quality dependent on variables of organizational character and, 
above all, of experience concerning quality management? The frame of the analysis necessary for answering those questions is shown in Figure 2.

\subsection{Internal and External Quality}

The idea that the total impact of the company on the market, and in business in general, can be achieved through long-term improvement of product quality represents, in fact, a cornerstone of contemporary quality revolution. Consumers form their impressions about the products of a company based on their own experience with their usage (Garvin, 1987).

Internal quality may be explained as the ability of companies to produce products in accordance with the designed quality, with the lowest possible production costs. It could be seen as a dimension of quality, which means "conformance with the requirements", as stated by Crosby $(1979,1996)$. As a measure of internal quality can be considered: the rate of waste, the rate of revision, the rate of defects, the result of the internal test quality (pre-shipment). However, a lower percentage of the defective outputs can be very expensive if quality is not provided during production. Efficient manufacturing processes are associated with higher productivity (Schonberger, 1986). Cost effectiveness of the production process is reflected through waste - defects and revisions that occur during production. These are the costs of the failure of internal quality (Juran and Gryna, 1993). They require additional engagement, which is reflected to productivity. Therefore, it is necessary to include the productivity of labor as an additional measure of internal quality.

Figure 2 Model of influence of Design and Process Management to Quality

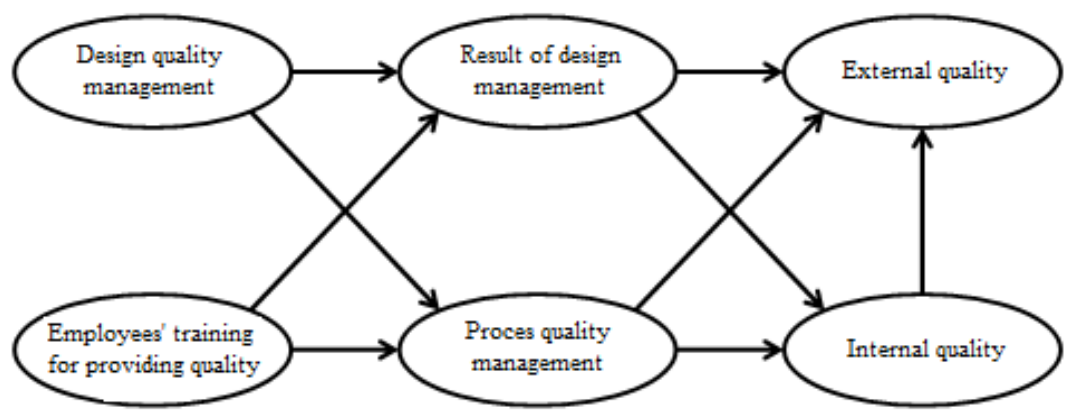

Satisfactory performances of the product on the market is followed by less customer dissatisfaction, customer loyalty and increased market share (Crosby, 1979). This aspect of quality is referred to as external quality because it is linked to the events following the delivery of the product to the consumer. This corresponds Juran's dimension of product quality, which he called a "fitness for use" (Juran and Gryna, 1993). Finally, it may be concluded that the internal quality has a positive effect on the external quality. 


\subsection{Quality of Product Design}

Successful companies use quality of product design as an important means of market leadership. The variety of products offered by a company depends on the speed and quality of their development (Bass, Klein, Bachmann, 2002).

The company's ability to outperform competitors in terms of product diversity, boils down on two main results of the process of designing products. The first source of competitive ability is the speed of new product development. Another source of competitive ability is to simplify the design and provide standardization of the product components. Both sources affect the cost and performances of production through their impact on the number of parts that the product consists of. Standardization of components in production lines significantly reduces the costs associated with inventory (Schonberger, 1986; Melnyk and Denzler, 1996). Quality of design has a direct impact on the external and internal quality.

Reducing the number of parts enables employees to quickly produce new products, working with the previously designed and built components that have standard costs, bills of materials and implementation time (Melnyk and Denzler, 1996). Since the complexity of the process is function of the complexity of the design, efficient production should result in fewer parts of components per product. A simplified production and previous experience of workers with standardized parts should, also, lead to less waste and repairs and a small number of defective products (Schonberger, 1986). Therefore, it may be said that the design of the product has a positive impact on the internal quality.

Quality of product design and delivery speed of new products to market wins and retains their customers. Also, agile innovators can better anticipate and respond to current and latent needs and preferences of consumers. Therefore, they should have fewer problems with consumer dissatisfaction. Such companies would also need to be able to maintain market leadership in their field. Therefore, it may be said that the design of the product has a positive effect on the external quality.

\subsection{Process Quality Management}

A process is a set of interrelated resources and activities that transform inputs into outputs. From this element largely depends the quality and satisfaction of consumers and, therefore, realized profits (Boskovic, 2004). Deming (1986) was a prominent advocate of process quality management, as a means to optimize the results, which are achieved during it. Production processes of lower quality levels consume more resources due to the defects and mistakes that occur both in the work process, and with the finished product at the final stage of control. According to some authors (Taguchi, 1987), the costs of 
nonconformance are increasing with growing deviation from the target quality. Therefore, process quality management is often cited as the main dimension of integrated efforts to achieve quality (Shingo, 1986). However, in order to achieve a higher quality of the process, it is impossible to focus attention to all the processes. Zahir and Rana (1995) indicates that efforts should be focused on the key processes which, in fact, represent a significant potential for gaining profits.

Process quality management essentially involves identifying the critical points of the production process and improving them, in order to provide superior quality of products, with costs effectiveness. It could be seen as a continuous activity, which consists of four stages: (1) selection of key processes based on quality costs (Ahire and Rana, 1995) and consumers demands, (2) identification of the main causes of problems in selected processes (Robinson and Schroeder, 1990) ( 3) implementation of changes by using corrective actions, to complete the redesign process (Schingo, 1986) and (4) measuring improvements in the process (Ahire, 1997). Juran (1992) and Deming (1986) have stressed the importance of measuring waste - defects and mistakes in the production process, in order to identify key processes and monitoring improvements in problem areas. Deming has specifically advocated the use of Statistical Process Control (SPC), to monitor the effect of the process, in order to ensure quality during production.

Responsible manager should describ (document) choosen key processes, identify problems, the basic sources of the problem and, finally, develop a system to improve the process. The procedure for documenting the process includes the following (Reid, Sanders, 2008):

- What activities are carried during process, with the sequence of the performance;

- Who carries out those activities (who is responsible for their realization);

- Important activities in the process and links with other processes (related procedures);

- Who controls the realization of certain activities;

- Which documents are used to perform certain activities and which are formed based on these activities (documents and reports).

As efforts are made to identify problem areas in production and take corrective actions to eliminate quality problems, smaller number of defective products will appear. Also, according to Taguchi's (1987) quadratic loss function, fastening parameters around the optimal level should lead to lower costs of poor quality, including costs related to scrap, waste and the modifications. Thus, quality management process has a positive impact on the internal quality.

In recent years, as the importance of Total Quality Management (TQM) is increasingly accepted, many companies have tried to establish direct 
communication between consumers and employees in production, in order to solve their complaints regarding defects in products more successfully, provide feedback on the quality of products and offer suggestions for future product improvements. In this way, company provides effect on the external and quality.

\subsection{Design Management}

The literature on product innovation indicates that the process of design management determines the performance of the products (Wheelwright and Clark, 1992) and that design management is an important element of integrated efforts to achieve quality (Zahir et al., 1996).

Successful innovative companies timely identify current and latent needs of consumers. They then transmit those identified needs to the relevant concepts of new products or enhanced features of existing products. Finally, they manage to show innovation to the market before competitors (Deschamps and Nayak, 1995).

Quality design and product innovation require a so-called cross-functional orientation and simultaneous processes of production and design planning (Deschamps and Nayak, 1995), or engineering approach, including participants from all parts of the value chain (Swink et al., 1996). Participation of consumers and marketing function in the design process provide relevant product design. Timely feedback from production function confirms or denys the technical feasibility of the idea. Finally, coordination between the research and development (R\&D), procurement and production improves design quality, too (Wheelwright and Clark, 1992). Quality design of products and related processes provided in this way, is closely associated with specific design strategies, such as the standardization of components. Hence, design management has a positive influence to the final product design.

Literature on quality management describes the cross-functional integration efforts for achieving quality as something that is conditioned by teamwork, cooperation and culture oriented towards quality (Mirvis, 1997). Members of organizations that participate in the processes of design management at the same time manage the process quality. Their knowledge, experience and attitudes regarding teamwork, in terms of product design, should spill over to the efforts concerning improving the quality of production processes (Sethi, 2000; Tsai, 2001). Hence, design management has a positive impact to the process quality management.

\subsection{Employee Training for Reaching Wanted Quality Level}

It has been known for a long time that a well-focused training of employees to achieve the quality is necessary for better process quality management (Juran, 1992; Robinson and Schroeder, 1993). Some authors suggest that providing 
employees with specialized skills in relation to quality management in general, enables them to contribute more to process quality management (Schonberger, 1986; Melnyk and Denzler, 1996). Thus, training for achieving a higher level of quality has a positive impact on the process quality management.

Training to achieve a higher level of quality usually includes the preparation for the application of process quality control methods, such as statistical methods of process quality control. Specialized training for reaching quality includes also preparing employees for using tools for solving problems related to the quality and group decision-making, and implementation tools for product design (Modarress and Ansari , 1989), such as Quality Function Deployment (QFD) and Design of Experiments (DoE). This means that training for achieving a higher level kvaliateta a positive impact on product design.

Companies that respect their consumers and try to engage them into the process of product design, consider important instrument known as Quality Function Deployment. Although this is a common name in the meaning of this tool may be more appropriate to call the "construction of quality function" or "developing quality characteristics". Tool has been promoted by Japanese professors Yoji Akao and Shigeru Mizuno (1994), with the intention to take into account the requirements of consumers when designing the product, and the first time was used in the Toyota (Boskovic, Anđelković-Pešić, 2011, p. 160). Successful implementation of this tool assumes cooperation of employees from different areas, such as marketing, research and development, finance and production, which involves teamwork, precisely creating a cros-functional team. A team of experts from these areas need to perform certain activities, as shown in table 1.

Table 1 Activities of Team for Product Design

\begin{tabular}{|l|l|}
\hline$>$ & Preparing the list of consumers' demands \\
\hline$>$ & Ranking of demands according to priority for consumers \\
\hline$>$ & Assesing competitors' products \\
\hline & $\begin{array}{l}\text { Creating the list of technical characteristics of product (as reflection of } \\
\text { company's capabilities) }\end{array}$ \\
\hline$>$ & Connecting technical characteristics with consumers' demands \\
\hline$>$ & Translating consumers' demands and data from competitors' analysis into \\
\hline & products' characteristics \\
\hline & Translating products' characteristics into specifications and defining \\
\hline$>$ measures \\
\hline$>$ Translating specifications into product design \\
\hline
\end{tabular}


The condition for the successful design is to collect data on consumer demands, and then translate them into concrete operational and engineering goals through the matrix, which is known as the "House of Quality", to ensure that the right priorities for improvement the existing design or create a new one have been selected.

Based on collected information on consumer demand, as well as the resources and capabilities that a company has, and which are suitable for meeting these demands, already formed team of experts defines one or a small number of new design concepts. In the next step, it is necessary to assess these concepts and choose one of them. The design concept shows which new or improved features will have a product that is the subject of improvement, or which activities or resources should be changed in order to improve certain process. Accordingly, the employees involved into design team, except the fact that should be from different business functions (usually from R\&D, production, marketing and procurement), should also be trained for using the tools for designing process, such as: Development and evaluation of the design concept, Quality function deployment, Priority ranking, Theory of inventive problem solving, Robust design, Design of experiment, Engineering and value analysis.

\section{Analysis of Design Quality Level in Enterprises in the Republic of Serbia: Methodology, Results and Discussion}

As based on the theoretical analysis of the importance and the success factors of the design process can be observed, the quality of design process is conditioned by the cooperation between the company functions, primarily those which are directly involved into design process. As it is already mentioned, these are: research and development, production, marketing and procurement. On the other hand, the factors that affect the quality of design process are: training of employees, application of quality management tools, and application of quality design tools. In order to identify the manner and the level of integration of business functions or departments involved in design process, empirical research has been conducted. Starting from a sample of 300 most successful companies in 2013 in the Republic of Serbia, a sample of 124 companies has been formed, which means that a response rate is $41.3 \%$. This rate can be considered as very high.

Therefore, the aim of the research is to determine if these functions in companies in the Republic of Serbia are related to each other, as suggested in theory, and to determine whether mentioned factors are cause the connection or disconnection. In order to reach the stated goal, it is necessary to identify the level of integration between those functions and determine to what extent the relationship between them is conditioned by the mentioned factors of successful 
design, precisely employee training, quality management tools and quality design tools. Initial assumptions of research are:

H1: Between research and development, production, marketing and procurement, as functions involved in the design process, there is a connection,

H2: Employee training, application of quality management tools and application quality design tools affect the establishment of links between research and development, production, marketing and procurement.

The answer whether these hypotheses should be accepted or rejected can be based an the analysis of the research data, collected through a questionnaire, to which questions have been answered by managers who are responsible for some of the features included in the design process. During the survey, managers of the companies in the sample presented their observations about the relationship between the functions involved in the design process (it should be noted that for questions concerning the level of integration score 1 means that there is a competition relationship between the functions, scores from 2 to 4 mean that a relationship is based on cooperation, while score 5 means that there is a relationship based on co-evolution).

By using descriptive statistical analysis it was found that in most companies the strongest link exists between the Production and Procurement (3.40), then between Marketing and R\&D (3.22), but also between Production and R\&D (3.14). More accurate data, including the standard deviation are given in Table 2.

Table 2 Descriptive Statistics - Testing Dependability between the Functions

\begin{tabular}{||l|r|r|r||}
\hline & Sample size & \multicolumn{1}{|c|}{ Mean } & Std. deviation \\
\hline Production and R\&D & 124 & 3.1452 & .86197 \\
\hline Production and Procurement & 124 & 3.4032 & .68574 \\
\hline R\&D and Procurement & 124 & 3.0887 & .83629 \\
\hline Marketing and R\&D & 124 & 3.2258 & .80485 \\
\hline Production and Marketing & 124 & 2.8387 & .95753 \\
\hline
\end{tabular}

In order to determine whether the companies are consistent in linking the functions, correlation analysis is applied. This analysis shows the level of quantitative agreement between the observed variables, in this case it is the relationships between the observed functions. Based on the results of correlation analysis (Table 3) it can be seen that the highest correlation coefficient is the one between Production and R\&D, as well as between Marketing and R\&D (0.632), meaning that these three functions, in fact, are mutually interrelated. A similar situation arises again, but it can be seen that once again it concerns the relation between these functions (Marketing and $R \& D$ vs. Production and Marketing - 0.575). Slightly lower, but still significant is the correlation 
coefficient between the variables Production and Procurement and R\&D and Procurement (0.405), meaning that these three functions are often closely linked in the companies in Serbia. These results are good, but not enough, because it is desirable that all functions are closely linked.

Tabele 3 Correlation Analysis of Cooperation between the Functions

\begin{tabular}{|c|c|c|c|c|c|c|}
\hline & & $\begin{array}{l}\text { Production } \\
\text { and R\&D }\end{array}$ & \begin{tabular}{|c|} 
Production \\
and \\
Procurement
\end{tabular} & $\begin{array}{c}\text { R\&D and } \\
\text { Procurement }\end{array}$ & $\begin{array}{l}\text { Marketing } \\
\text { and R\&D }\end{array}$ & $\begin{array}{l}\text { Production } \\
\text { and } \\
\text { Marketing }\end{array}$ \\
\hline \multirow{3}{*}{$\begin{array}{r}\text { Production } \\
\text { and } R \& D\end{array}$} & $\begin{array}{l}\text { Correlation } \\
\text { coefficient }\end{array}$ & 1 & .024 & .038 & $.632(* *)$ & $.364(* *)$ \\
\hline & $\begin{array}{l}\text { Significance } \\
\text { level }\end{array}$ & & .792 & .672 & .000 & .000 \\
\hline & Sample size & 124 & 124 & 124 & 124 & 124 \\
\hline \multirow{3}{*}{$\begin{array}{l}\text { Production } \\
\quad \text { and } \\
\text { Procurement }\end{array}$} & $\begin{array}{l}\text { Correlation } \\
\text { coefficient }\end{array}$ & .024 & 1 & $.405(* *)$ & .099 & .100 \\
\hline & $\begin{array}{l}\text { Significance } \\
\text { level }\end{array}$ & .792 & & .000 & .275 & .270 \\
\hline & Sample size & 124 & 124 & 124 & 124 & 124 \\
\hline \multirow{3}{*}{$\begin{array}{l}\mathrm{R} \& D \text { and } \\
\text { Procurement }\end{array}$} & $\begin{array}{l}\text { Correlation } \\
\text { coefficient }\end{array}$ & .038 & $.405(* *)$ & 1 & .030 & $.282(* *)$ \\
\hline & $\begin{array}{l}\text { Significance } \\
\text { level }\end{array}$ & .672 & .000 & & .738 & .002 \\
\hline & Sample size & 124 & 124 & 124 & 124 & 124 \\
\hline \multirow{3}{*}{$\begin{array}{l}\text { Marketing and } \\
\text { R\&D }\end{array}$} & $\begin{array}{l}\text { Correlation } \\
\text { coefficient }\end{array}$ & $.632(* *)$ & .099 & .030 & 1 & $.575(* *)$ \\
\hline & $\begin{array}{l}\text { Significance } \\
\text { level }\end{array}$ & .000 & .275 & .738 & & .000 \\
\hline & Sample size & 124 & 124 & 124 & 124 & 124 \\
\hline \multirow{3}{*}{$\begin{array}{l}\text { Production } \\
\text { and } \\
\text { Marketing }\end{array}$} & $\begin{array}{l}\text { Correlation } \\
\text { coefficient }\end{array}$ & $.364(* *)$ & .100 & $.282(* *)$ & $.575(* *)$ & 1 \\
\hline & $\begin{array}{l}\text { Significance } \\
\text { level }\end{array}$ & .000 & .270 & .002 & .000 & \\
\hline & Sample size & 124 & 124 & 124 & 124 & 124 \\
\hline
\end{tabular}

** Correlation is significant for 0.01 .

As factors that affect the quality of the design process, based on the results of theoretical research, identified are training of employees, application of quality management tools, and application of quality design tools. Descriptive statistics for these variables is given in Table 4. 
Table 4 Descriptive Statistics - Design Quality Factors

\begin{tabular}{|l|r|r|r|}
\hline & \multicolumn{1}{|c|}{$\begin{array}{c}\text { Sample } \\
\text { size }\end{array}$} & \multicolumn{1}{c|}{ Mean } & Std. deviation \\
\hline Employee training & 124 & 3.1129 & .83821 \\
\hline Quality management tools & 124 & 3.0000 & .90167 \\
\hline Quality design tools & 124 & 2.8710 & 1.01186 \\
\hline
\end{tabular}

Results of descriptive statistics show that the mostly present variable is Employee training (3.11), while the least present are Quality design tools (2.87). However, it appears that differences in the average scores of these variables are not significant, noting that the standard deviation for the last variables is largest, which means that there are the greatest differences in the attitudes of managers.

Table 5 Correlation Analysis of Cooperation between the Factors

\begin{tabular}{|c|c|c|c|c|}
\hline & & $\begin{array}{l}\text { Employee } \\
\text { training }\end{array}$ & $\begin{array}{c}\text { Quality } \\
\text { management } \\
\text { tools } \\
\end{array}$ & $\begin{array}{l}\text { Quality design } \\
\text { tools }\end{array}$ \\
\hline \multirow{3}{*}{$\begin{array}{l}\text { Employee } \\
\text { training }\end{array}$} & $\begin{array}{l}\text { Correlation } \\
\text { coefficient }\end{array}$ & 1 & $.710(* *)$ & $.458(* *)$ \\
\hline & $\begin{array}{l}\text { Significance } \\
\text { level }\end{array}$ & & .000 & .000 \\
\hline & Sample size & 124 & 124 & 124 \\
\hline \multirow{3}{*}{$\begin{array}{c}\text { Quality } \\
\text { management } \\
\text { tools }\end{array}$} & $\begin{array}{l}\text { Correlation } \\
\text { coefficient }\end{array}$ & $.710(* *)$ & 1 & $.419(* *)$ \\
\hline & $\begin{array}{l}\text { Significance } \\
\text { level }\end{array}$ & .000 & & .000 \\
\hline & Sample size & 124 & 124 & 124 \\
\hline \multirow{3}{*}{$\begin{array}{c}\text { Quality } \\
\text { design tools }\end{array}$} & $\begin{array}{l}\text { Correlation } \\
\text { coefficient }\end{array}$ & $.458(* *)$ & $.419(* *)$ & 1 \\
\hline & $\begin{array}{l}\text { Significance } \\
\text { level }\end{array}$ & .000 & .000 & \\
\hline & Sample size & 124 & 124 & 124 \\
\hline
\end{tabular}

** Correlation is significant for 0.01 .

When it is about factors of the design process, the level of quantitative agreement is high or very high, indicating that their application is often associated. Among the variables Employee training and Quality management tools correlation coefficient is 0.710, between variables Employee training and Quality design tools 0.458 , while between variables Quality management tools and Quality design tools correlation coefficient is equal 0.419 .

In order to test whether these factors really affect the quality of the design process, or whether they affect the correlation of the observed functions, 
regression analysis was used. This analysis examines the relationship between two or more variables, wherein the at least one is independent variable and one dependent. The following table shows the results of the regression analysis (Table 6).

Table 6 Regression Analysis

\begin{tabular}{|c|c|c|c|c|c|c|}
\hline \multicolumn{2}{|c|}{ Variables } & \multicolumn{2}{|c|}{$\begin{array}{l}\text { Unstandardized } \\
\text { coefficient }\end{array}$} & \multirow{2}{*}{$\begin{array}{c}\text { Standardized } \\
\text { coefficient }\end{array}$} & \multirow[t]{2}{*}{$\mathrm{t}$} & \multirow{2}{*}{ Sig. } \\
\hline Dependent & Independent & $\mathrm{B}$ & Std. error & & & \\
\hline $\begin{array}{c}\text { Production and } \\
\text { Procurement }\end{array}$ & $\begin{array}{c}\text { Quality } \\
\text { management } \\
\text { tools }\end{array}$ & .280 & .094 & .368 & 2.980 & .003 \\
\hline $\begin{array}{c}\text { R\&D and } \\
\text { Procurement }\end{array}$ & $\begin{array}{c}\text { Quality } \\
\text { design tools }\end{array}$ & .216 & .079 & .261 & 2.719 & .008 \\
\hline \multirow{2}{*}{$\begin{array}{l}\text { Marketing } \\
\text { and R\&D }\end{array}$} & $\begin{array}{c}\text { Quality } \\
\text { management } \\
\text { tools } \\
\end{array}$ & .324 & .087 & .363 & 3.750 & .000 \\
\hline & $\begin{array}{c}\text { Quality } \\
\text { design tools }\end{array}$ & .204 & .061 & .257 & 3.341 & .001 \\
\hline \multirow{3}{*}{$\begin{array}{c}\text { Production and } \\
\text { Marketing }\end{array}$} & $\begin{array}{c}\text { Employee } \\
\text { training }\end{array}$ & .414 & .103 & .362 & 4.011 & .000 \\
\hline & $\begin{array}{c}\text { Quality } \\
\text { management } \\
\text { tools }\end{array}$ & .305 & .094 & .287 & 3.248 & .002 \\
\hline & $\begin{array}{c}\text { Quality } \\
\text { design tools }\end{array}$ & .217 & .066 & .229 & 3.270 & .001 \\
\hline
\end{tabular}

Table 6 contains only the regression coefficients based of which it can be concluded that at presented relations there is regression, and consequently the influence of independent variables to the dependent ones. The same conclusion can be reached based on the level of significance, which is all cases less than 0.01 . The conclusion is that the observed factors only do not have a statistically significant effect in terms of the relations of Production and R\&D, while for other links between the functions this effect is present.

Bearing in mind that based on regression analysis cannot be generalized whether the observed factors affect the establishment of links between the functions involved in the design process, cluster analysis was conducted. $K$ means method has been used. The grouping of companies into clusters was performed on two grounds: first, based on the connection between the functions (Tables 7 and 8), and then based on the presence of the observed factors (Tables 9 and 10).

Based on the data for clusters it can be seen that the companies that belong to the first cluster ( 65 companies) characterize higher average marks in relation 
to the companies that belong to the second cluster (59 companies). This means that in the companies from the first cluster there is pronounced correlation between the observed function.

Table 7 Final Cluster Centres

\begin{tabular}{||l|r|r||}
\hline \multirow{2}{*}{\multicolumn{1}{|c|}{ Functions }} & \multicolumn{2}{c|}{ Clusters } \\
\cline { 2 - 3 } & 1 & \multicolumn{1}{c|}{2} \\
\hline Production and R\&D & 3.69 & 2.54 \\
\hline Production and Procurement & 3.49 & 3.31 \\
\hline R\&D and Procurement & 3.29 & 2.86 \\
\hline Marketing and R\&D & 3.82 & 2.58 \\
\hline Production and Marketing & 3.45 & 2.17 \\
\hline
\end{tabular}

Table 8 Number of Enterprises Inside Clusters

\begin{tabular}{|r|r|r|}
\hline \multirow{2}{*}{ Clusters } & 1 & 65.000 \\
\cline { 2 - 3 } & 2 & 59.000 \\
\hline & Total & 124.000 \\
\hline
\end{tabular}

Table 9 Final Cluster Centres

\begin{tabular}{|l|r|r|}
\hline \multirow{2}{*}{\multicolumn{1}{|c|}{ Factors }} & \multicolumn{2}{c|}{ Clusters } \\
\cline { 2 - 3 } & 1 & \multicolumn{1}{c|}{2} \\
\hline Employee training & 3.51 & 2.33 \\
\hline Quality management tools & 3.39 & 2.24 \\
\hline Quality design tools & 3.41 & 1.81 \\
\hline
\end{tabular}

Table 10 Number of Enterprises Inside Clusters

\begin{tabular}{|l|r|r|}
\hline \multirow{2}{*}{ Clusters } & 1 & 82.000 \\
\cline { 2 - 3 } & 2 & 42.000 \\
\hline \multicolumn{3}{|r|}{ Total } \\
\hline
\end{tabular}

Also, based on data by the clusters it can be seen that the companies that belong to the first cluster ( 82 companies) are characterized by higher average marks in relation to the companies that belong to the second cluster (42 companies). This means that in the companies from the first cluster there is prominent employee training and the application of quality management tools and quality design tools. 
Finally, verification of claims about the impact of the above mentioned factors on business functions connection has been done by using correlation analysis based on belonging of the companies to previously presented clusters (Table 11).

Table 11 Correlation Analysis Based on Belonging to the Clusters

\begin{tabular}{|c|c|c|c|}
\hline & & $\begin{array}{l}\text { Belonging to the } \\
\text { clusters according } \\
\text { to the functions }\end{array}$ & $\begin{array}{l}\text { Belonging to the } \\
\text { clusters according } \\
\text { to the factors }\end{array}$ \\
\hline \multirow{3}{*}{$\begin{array}{l}\text { Belonging to the } \\
\text { clusters according } \\
\text { to the functions }\end{array}$} & Correlation coefficient & 1 & $.717(* *)$ \\
\hline & Significance level & & .000 \\
\hline & Sample size & 124 & 124 \\
\hline \multirow{3}{*}{$\begin{array}{l}\text { Belonging to the } \\
\text { clusters according } \\
\text { to the factors }\end{array}$} & Correlation coefficient & $.717(* *)$ & 1 \\
\hline & Significance level & .000 & \\
\hline & Sample size & 124 & 124 \\
\hline
\end{tabular}

** Correlation is significant for 0.01 .

The correlation coefficient between the variables (belonging to the clusters) is 0.717 , which is a very high. This value of the correlation coefficient indicates that among the observed variables there is a strong relationship, which finally allows the conclusion that between the observed factors: employee training and the application of quality management tools and quality design tools and connectivity business functions involved in the design process there is a strong correlation, and that these factors really influence the establishment of links between functions.

\section{Conclusion}

To achieve the quality of product functioning (product's ability to function effectively during the period of use by the consumer), it is important to manage all dimensions of quality, particularly the quality of design and quality of the processes.

The design affects quality from the consumer standpoint, through visible changes of the product - to perception on external quality, but primarily on internal quality - through its contribution to the efficient production of high quality products. However, the company should not always necessary strive to revolutionary improvements of product characteristics. These efforts should be balanced with the ongoing improvements in efficiency and production costs. The proposed model of synergy between the management of the design and management of process is useful for both, large and small businesses, for enterprises with different levels of TQM experience and different characteristics of the production process. 
Education and training of employees, and the use of resources to provide quality are also useful in achieving a high level of quality of product design and quality of processes. These exogenous factors affect the internal quality measures (waste or scrap rates and correction of products), as well as external quality measures (market share, consumer complaints, the cost of servicing the product within the warranty period, etc.).

The accuracy of theoretical assumptions are confirmed by the results of empirical research. Among other things, those results show that the observed factors (training of employees, the application of quality management tools and application quality design tools) affect the connectivity between business functions (production, R\&D, marketing and procurement). This conclusion proceeds from the significance level, which, in all presented cases, is less than 0.01 .

However, regression analysis did not show uniform results, so it cannot be the basis for making a general conclusion about the influence of observed factors on linkages between the observed business functions. Therefore, cluster analysis was performed, and then the correlation analysis, too. The results of these analysis confirmed the assumption identified after the theoretical analysis, which is that there is an impact of employee training, application of quality management tools and quality design tools, as factors, to establishing connections between the functions involved in the design process. This means that the application of appropriate tools and training of employees for the application of those tools can encourage the connection of employees engaged in certain functions, and also encourage teamwork and thus provide synergic effects in the design process, which will it quality.

\section{References}

Ahire, S. L. (1997) "Management Science - Total Quality Management Interfaces: An Integrative Framework", Interfaces, 27 (6): 91-114.

Ahire, S. L., D. Y. Golhar, and M. A. Waller (1996) "Development and Validation of TQM Implementation Constructs", Decision Sciences, 27 (1): 23-56.

Ahire, S. L. and D. S. Rana (1995) "TQM pilot projects selection using an MCDM approach", International Journal of Quality and Reliability Management, 12 (1): 61-81.

Amitava, M. (1994) Fundamentals of Quality Control and Improvement, New York: Macmillan.

Bass, L., M. Klein, and F. Bachmann (2002) Quality Attribute Design Primitives and the Attribute Driven Design Method, Berlin: Springer.

Bass, F. M. (2004) "Comments on a New Product Growth for Model Consumer Durables the Bass Model”, Management science, 50 (12): 1833-1840.

Benton, W.C. (1991) "Statistical process control and the Taguchi method: a comparative evaluation", International Journal of Production Research, 29 (9): 1761-1770.

Bošković, G. (2004) Upravljanje kvalitetom u industriji, Niš: Ekonomski fakultet. 
Bošković, G. and M. Anđelković-Pešić (2011) Upravljanje kvalitetom - osnova konkurentnosti preduzeća i privrede, Niš: Ekonomski fakultet.

Chase, R. B., F. R. Jacobs, and N. J. Aquilano (2006) Operations Management for Competitive Advantage with Global Cases, New York: McGraw-Hill.

Crosby, P. B. (1979) Quality Is Free, New York, NY: McGraw-Hill.

Crosby, P.B. (1996) Quality Is Still Free, New York, NY: McGraw-Hill

Deming, W. E. (1986) Out of the Crisis, Cambridge, MA: MIT Press.

Deschamps, J. P. and R. Nayak (1995) Product Juggernauts: How Companies Mobilize to Generate a Stream of Market Winners, Boston (MA): Harvard Business School Press.

Flynn, B. B., R. G. Schroeder, and S. Sakakibara (1995) "The impact of quality management practices on performance and competitive advantage", Decision Sciences, 26 (5): 659-692.

Garvin, D. A. (1987) "Competing on the eight dimensions of quality", Harvard Business Review, 65 (6): 101-109.

Gruner, K. E. and Homburg, C. (2000) "Does Customer Interaction Enhance New Product Success?", Journal of business research, 49 (1): 1-14.

Juran, J. (1992) Juran on Quality by Design: The New Steps for Planning Quality into Goods and Services, Southbury, CT: Juran Institute, The Free Press.

Juran, J. M. and F. M. Gryna (1993) Quality Planning and Analysis, New York, NY: McGraw-Hill.

Lukas, B. A. and Menon, A. (2004) "New Product Quality: Intended and Unintended Consequences of New Product Development Speed", Journal of Business Research, 57 (11): 1258-1264.

Melnyk, S. A. and D. R. Denzler (1996) Operations Management: A Value-Driven Approach, Chicago, IL: Irwin.

Mirvis, P. H. (1997) "Human resource management: leaders, laggards, and followers", Academy of Management Executive, 11 (2): 43-56.

Mizuno, S. and Y. Akao (1994) QFD: The Customer-Driven Approach to Quality Planning and Deployment, Hong Kong: Nordica International.

Modarress, B. and A. Ansari (1989) "Quality control techniques in US firms: A survey", Production and Inventory Management Journal, 30 (2): 58-62.

Reid, D. and Sanders, N. (2008) Operations Management: An Integrated Approach, Trenton, NJ: John Wiley and Sons.

Robinson, A. G. and D. M. Schroeder (1990) “The limited role of statistical quality control in a zero-defect environment", Production and Inventory Management Journal, 31 (3): 60-65.

Robinson, A. G. and D. M. Schroeder (1993) "Training, continuous improvement, and human relations: the US TWI programs and the Japanese management style", California Management Review, 35 (2): 35-57.

Schonberger, R. J. (1986) World Class Manufacturing: The Lessons of Simplicity Applied, New York, NY: Free Press.

Sethi, R. (2000) "New Product Quality and Product Development Teams", The Journal of Marketing, 64 (2): 1-14. 
Shingo, S. (1986) Zero Quality Control: Source Inspection and The Poka-yoke System, Stamford, CT: Productivity Press.

Swink, M. L., V. A. Mabert, and J. C. Sandvig (1996) "Customizing concurrent engineering processes: five case studies", Journal of Product Innovation Management, 13, 229-244.

Taguchi, G. (1987) On-line Quality Control during Production, Tokyo, Japan: Japanese Standards Association.

Tsai, W. (2001) "Knowledge Transfer in Intraorganizational Networks: Effects of Network Position and Absorptive Capacity on Business Unit Innovation and Performance", Academy of management journal, 44 (5): 996-1004.

Van Kleef, E., Van Trijp, H. and Luning, P. (2005) "Consumer Research in the Early Stages of New Product Development: A Critical Review of Methods and Techniques", Food Quality and Preference, 16 (3): 181-201.

Wheelwright, S. C. and K. B. Clark (1992) Revolutionizing New Product Development: Quantum Leaps in Speed, Efficiency, and Quality, New York, NY: The Free Press.

\section{ANALIZA FAKTORA I EFEKATA KVALITETA DIZAJNA PROIZVODA}

Apstrakt: Cilj rada je da ukaže na činjenicu da postoji izražena veza između kvaliteta dizajna i kvaliteta procesa, a posledično i kvaliteta gotovih proizvoda (interni kvalitet), te $\mathrm{u}$ konačnom i kvaliteta funkcionisanja proizvoda (eksterni kvalitet). U radu se daje nacrt modela sinergije između upravljanja dizajnom i upravljanja procesom. Kako je kvalitet dizajna prva karika u ovom lancu kreiranja kvaliteta, to je neophodno adekvatno sprovesti proces dizajniranja, odnosno obezbediti kvalitetno dizajniranje. Kvalitetno dizajniranje podrazumeva povezanost i saradnju funkcija koje mogu dati doprinos procesu dizajniranja, a to su: istraživanje i razvoj, proizvodnja, marketing i nabavka. Da bi se to postiglo, značajno je u kontinuitetu raditi na obrazovanju i obuci zaposlenih. Osim toga, potrebno je primenjivati alate karakteristične za obezbeđenje kvalitetnog dizajna, ali i opšte alate značajne za upravljanje kvalitetom. Prema tome, predmet rada jeste ispitivanje uticaja obuke zaposlenih, primene alata za upravljanje kvalitetom i primene alata za kvalitetno dizajniranje, kao faktora, na uspostavljanje veze između poslovnih funkcija koje bi trebalo da budu uključene u proces dizajniranja. Na osnovu primene alata poput regresione analize, klaster analize i korelacione analize, rezultati empirijskog istraživanja sugerišu da navedeni faktori utiču na uspostavljanje veze između posmatranih poslovnih funkcija, te da doprinose obezbeđenju kvaliteta procesa dizajniranja.

Ključne reči: kvalitet dizajna, kvalitet procesa, poslovne funkcije, klaster analiza, regresiona i korelaciona analiza. 